\title{
SWOT Analysis of Marketing Strategies Applied by MTDC for Promotion of Maharashtra Tourism
}

Harshada Satghare $^{*}$ and Madhuri Sawant ${ }^{\dagger}$

\section{Abstract}

With the increasing role of the Internet in Marketing, Destination Marketing Organisations (DMOs) are focusing on the application of the Internet in destination promotion activities. The present study aims to evaluate the application of Tourism Internet Marketing Strategies by Maharashtra Tourism Development Corporation (MTDC), India. Data Triangulation Method was used for detailed understanding of the phenomenon. Further, the researchers have provided a SWOT Analysis of these strategies, which would be helpful for destination planners and marketers in improving destination competitiveness.

Keywords: Tourism Internet Marketing, MTDC, DMO, SWOT Analysis, Data Triangulation

\section{Introduction}

The state of Maharashtra is an important tourism state in India, blessed with a large array of tourism products. MTDC is the DMO of the state which is responsible for marketing and management of tourism in the state (Elbe, Hallén, \& Björn, 2009; ETC \& UNWTO,

\footnotetext{
* Dr Babasaheb Ambedkar Marathwada University, Aurangabad (MS), India; harshada.satghare@gmail.com

† Dr Babasaheb Ambedkar Marathwada University, Aurangabad (MS), India ;drrmadhurisawant@gmail.com
} 
2003; Pike, 2004). Since 1975, MTDC is taking due efforts to promote the state as a world-class tourism destination utilising traditional as well as modern marketing channels. The objective of this Government body is to increase the tourist traffic into the state in the next five years by two-fold (MTDC, 2005). At the same time, previous research has highlighted the issue of non-availability of information, lack of foresightedness and market intelligence, and absence of aggressive marketing strategies that could act as a deterrence.

For this reason, the present research has performed a SWOT Analysis on the marketing strategies of MTDC, specifically focusing on the Internet Marketing Strategies as there is no noticeable research found in this particular area.

Data Triangulation Method has been used for Situation Analysis as it offers a process of verification that increases validity by incorporating several viewpoints and methods (Yeasmin \& Rahman, 2012). For this, data from tourists and the concerned MTDC official was collected. Further, the observations and detailed study of the researchers have provided useful insights and after a thorough understanding of the current situation, Strengths, Weaknesses, Opportunities, and Threats of the Marketing Strategies of Maharashtra Tourism have been listed.

\section{Literature Review}

Maharashtra State, which came into existence in the year 1960, is one of the most progressive states in India. Along with agriculture, it is known as an industrial state and its capital Mumbai is also considered as the economic capital of the country.

Maharashtra is a leading tourism state in the country, ranked second in foreign tourist arrivals and fifth in domestic tourist arrivals (MoT GoI, 2016). The state is blessed with numerous tourism products, including six world heritage sites (Ajanta caves, Ellora caves, Elephanta caves, Chhatrapati Shivaji Terminus Railway station, Victorian Gothic and Art Deco Ensembles of Mumbai and Western Ghats) and Western Ghats), $720 \mathrm{~km}$ of coastal line, well-known tiger reserves, Lonar Crater (third largest 
crater in the world), and many other cultural and natural tourism products.

Table 1 demonstrates that the last decade (i.e. from 2006-16) has witnessed a marginal growth of tourist arrivals in the state, and at the same time, the state rank has declined in both segments of tourists (Foreign and Domestic). It depicts the picture of an intense competitive environment at the national level. The State Ranking Report (Thadani \& Roy, 2017) demonstrated that Maharashtra's domestic tourist visitations have been outpaced by Andhra Pradesh and Madhya Pradesh, both of which have been aggressively targeting domestic tourists.

Table 1 Tourists arrivals in Maharashtra State from 2006-2016

\begin{tabular}{cccccc}
\hline $\begin{array}{c}\text { Sr. } \\
\text { No. }\end{array}$ & Year & $\begin{array}{c}\text { International } \\
\text { Tourist }\end{array}$ & Rank & $\begin{array}{c}\text { Domestic } \\
\text { Tourist }\end{array}$ & Rank \\
\hline 1. & 2006 & 1712302 & 2 & 16880348 & 6 \\
2. & 2007 & 1928052 & 2 & 19226716 & 7 \\
3. & 2008 & 2056913 & 2 & 20553360 & 6 \\
4. & 2009 & 2426362 & 1 & 30628394 & 4 \\
5. & 2010 & 5083126 & 1 & 48465492 & 4 \\
6. & 2011 & 4815421 & 1 & 55333467 & 5 \\
7. & 2012 & 2651889 & 2 & 74816051 & 5 \\
8. & 2013 & 4156343 & 1 & 82700556 & 5 \\
9. & 2014 & 4389098 & 2 & 94127124 & 4 \\
10. & 2015 & 4408916 & 2 & 103403935 & 5 \\
11. & 2016 & 4670049 & 2 & 116515801 & 6 \\
\hline
\end{tabular}

Source: Compiled by the researchers from Tourists Statistics report of Ministry of Tourism, Govt. of India from 2006 to 2016.

With the emerging internet technologies and increasing global competitiveness, DMOs are taking due efforts to develop worldclass internet marketing strategies for destination marketing (Tanrisevdi \& Duran, 2011; Yayli \& Bayram, 2010). Being the fastest growing branch of Marketing, Internet Marketing includes the use of the internet for achieving the marketing objectives of the organisation (Chaffey, Chadwick, Johnston, \& Mayer, 2015). Department of Tourism, Government of Maharashtra has recognised its need to reach out to newer target audiences through social and digital media. The Marketing Plan provided in the Tourism Policy of Maharashtra State - 2016 discusses the 
development of an Integrated $360^{\circ}$ Marketing Plan for improving online presence and developing website collaterals (GoM, 2016).

Figure 1 displays different marketing strategies applied by MTDC for the promotion of Maharashtra Tourism:
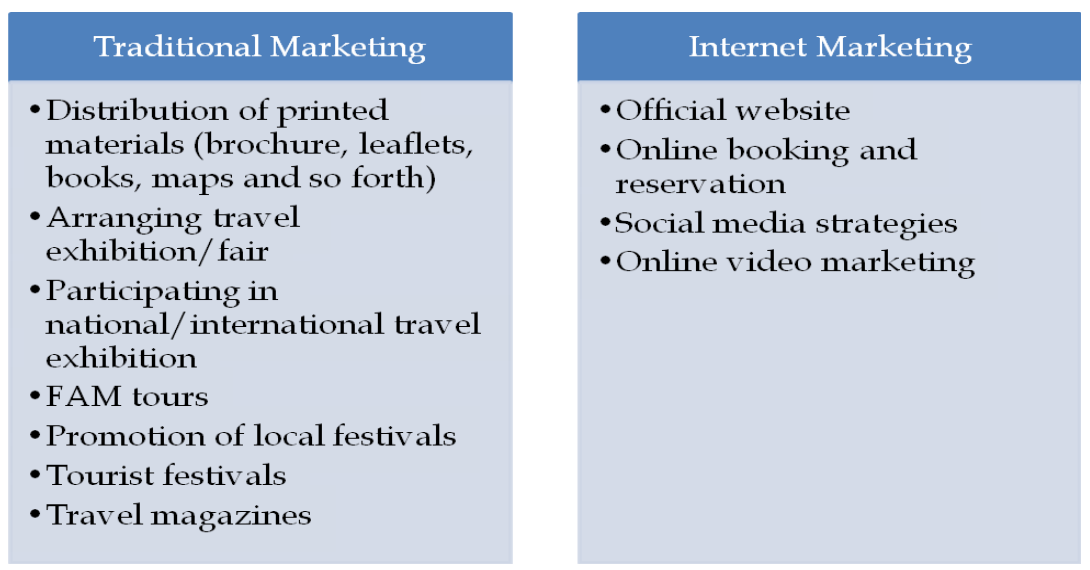

Fig 1 Different Marketing Strategies applied by MTDC for Promotion of Maharashtra Tourism

Though MTDC and other government agencies are taking due efforts for tourism promotion, many research studies have criticised them. The Marketing Campaign of MTDC was disparaged due to less visibility as compared to other states ("Maharashtra Tourism SWOT Analysis, USP \& Competitors," 2017). The dire need for focusing attention and research on media use and marketing and promotion of new and off-beat destinations was highlighted by researchers. An assertive use of internet marketing at the national and international levels was recommended to MTDC (Joshi, 2014).

SWOT Analysis of Maharashtra Tourism conducted by the Planning Commission of India (Tourism, 2014) highlighted the weaknesses of the non-availability of information and analytical data. The report explained that the state does not have a proactive information strategy to attract tourists at the decision-making point due to the ineffectiveness of the website and other online distribution channels. Though MTDC has taken steps in developing a website that offers useful information and at the same time 
promotes the potential of the state, the website needs to be regularly updated to give visitors the latest information on new destinations and developments. The report also suggested that the website should develop relationships with private operators to distribute their packages. Further, it explained that the state failed in achieving market intelligence as it does not maintain data related to tourist behaviour such as destination-wise sources, country-wise tourist arrivals, spending patterns, to name a few.

A State Ranking Survey conducted by Hotelivate.com and WTTC India Initiative (2017) assessed the relative competitiveness of India's 30 states, by analysing each individual state's potential for Travel and Tourism. One of the parameters for the assessment was the effectiveness of the marketing campaign that was based on expenditure for marketing, a ranking of the official website and outreach of the social media pages of the state. Maharashtra ranked fifth in the global ranking of the official website (dropped down from the third position in the year 2015), ninth for social media outreach and seventh in marketing expenditure, whereas the overall ranking of the state in marketing effectiveness was three; after Gujarat and Rajasthan. Thus, it was evident that though the state had spent Rs. 52, 49, 01, 469 on marketing, it was not reflected in the global ranking of the website nor on the social media outreach of the state. Hence the state had to take up serious steps in order to rectify the penetration of the website and social media platforms so as to improve visibility and thereby develop the overall brand recall.

More to the point, the survey conducted by MTDC (2015) revealed that a major source of information on Maharashtra Tourism was through the internet for the majority of the domestic (52.5\%) and foreign $(84.9 \%)$ tourists. It showed the importance of the internet as an Information Distribution Channel for MTDC. But the futile application of Internet Marketing by Maharashtra Tourism has resulted in the non-availability of information for potential tourists. Therefore, the present research aims to analyse the Destination Marketing Strategies, specifically the Internet Marketing Strategies of MTDC so as to improve the online marketing planning of the State Tourism. 
SWOT Analysis, a model widely used for analysing business (Stapenhurst, 2010), is also used for the study. It particularly examines the Strengths, Weaknesses, Opportunities, and Threats of the organisation. Observation of the Company's Strengths and Weaknesses deals with the study of the Internal Environment while the study of the Opportunities and Threats portrays the picture of the External Environment. After performing SWOT Analysis, appropriate planning can be undertaken to improve on the Weaknesses until they become Strengths and to take advantage of future Opportunities so as to counter the future Threats (Chaffey et al., 2015; Kotler, Keller, Koshy, \& Jha, 2013). Thus, Strategic Planning comprising of the right goals for Marketing of the State Tourism can be done.

\section{Research Methodology}

\section{1 Sampling}

Purposively, three World Heritage Sites of the state, namely Ajanta caves (Aurangabad), Ellora caves (Aurangabad) and Elephanta caves (Mumbai) were selected as sample destinations. Survey of 200 tourists visiting the sample destinations was conducted from February 23 to August 25, 2016, by using Simple Random Sampling technique.

An interview with the Marketing Manager of MTDC was also conducted at the Head Office of MTDC, Mumbai.

Table 2 Sampling for the Studv

\begin{tabular}{clcl}
\hline $\begin{array}{c}\text { Sr. } \\
\text { No. }\end{array}$ & \multicolumn{1}{c}{ Sample } & $\begin{array}{c}\text { Sample } \\
\text { Size }\end{array}$ & \multicolumn{1}{c}{ Sample Destination } \\
\hline 1 & $\begin{array}{l}\text { Survey of Tourists } \\
\text { at World Heritage } \\
\text { Sites of } \\
\text { Maharashtra }\end{array}$ & 200 & $\begin{array}{l}\text { Ajanta caves, Ellora caves, } \\
\text { Elephanta Caves }\end{array}$ \\
2 & $\begin{array}{l}\text { Interview of the } \\
\text { Marketing } \\
\text { Manager }\end{array}$ & 01 & $\begin{array}{l}\text { Head Office, MTDC, } \\
\text { Mumbai }\end{array}$ \\
\hline
\end{tabular}




\subsection{Data collection}

Both, primary and secondary data was collected for the study. Primary data was collected from tourists and the official from MTDC. A structured questionnaire was used as a research tool to conduct the survey at the sample destination. A semi-structured interview schedule was used for interviewing the official of MTDC.

Secondary data was collected from the review of MTDC reports and other publications, state tourism policy, journal articles, magazines, newspapers, statistical reports and government reports.

\subsection{Data analysis}

As mentioned, SWOT Analysis was performed. For more accurate and detailed understanding of the situation, data triangulation method was applied. According to Yeasmin and Rahman (2012), "the Data Triangulation Method refers to the combination of two or more theories, data sources, methods or investigators in one study of a single phenomenon so as to converge on a single construct, and it can be employed in both quantitative (validation) and qualitative (inquiry) studies".

In the present research study, quantitative data was collected through the survey of tourists and qualitative data was collected through an interview with the Marketing Manager. Descriptive Statistics was applied to quantitative data, while a detailed analysis of qualitative data was performed. Further, the researchers' observations were added to provide a more comprehensive insight into the data. Thus, triangulation of both the data and the method helped in an unambiguous understanding of the effectiveness of the present marketing strategies of MTDC. 


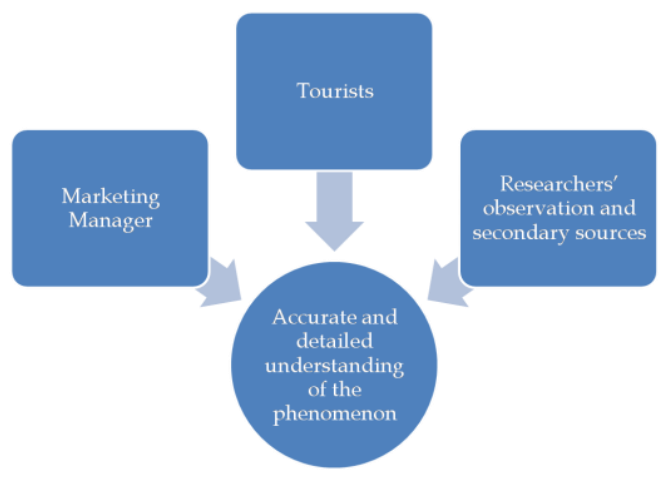

Fig 2 Data Triangulation Method used for the Study

\subsection{Research findings}

Tourists' Survey: Findings from the tourist survey put forward the undoubted role of the Internet as a major source of information for tourists, supporting the findings of the survey conducted by MTDC (2015). Internet as a medium is followed by friends and relatives, travel agencies, and tour operators. Further, promotional literature, print and audio-visual media also have a considerable role in information distribution.

Table 3 Various Sources of Information used by Tourists Visiting Maharashtra

\begin{tabular}{llc}
\hline Sr. No. & \multicolumn{1}{c}{ Source of Information } & Percentage \\
\hline 1 & Internet & 31.2 \\
2 & Friends and relatives & 26.2 \\
3 & Travel agencies/ tour operators & 18.6 \\
4 & Promotional literature & 9.0 \\
5 & Newspaper and print media & 6.5 \\
6 & TV / radio & 6.1 \\
7 & Other & 2.5 \\
\hline
\end{tabular}

The tourists were enquired as to whether they visited the official destination website of Maharashtra Tourism and the Social Media Pages of MTDC. The findings clearly exhibited the unawareness among the tourists as only $42 \%$ of the tourists had visited the official website (the majority of them checked it only for resort 
bookings) while only $27 \%$ of the tourists had seen the Social Media Pages of MTDC.

Table 4 Visit of Tourists to the Official Destination Website and Official Social Media Pages of MTDC

\begin{tabular}{llll}
\hline $\begin{array}{c}\text { Sr. } \\
\text { No. }\end{array}$ & \multicolumn{1}{c}{ Statement } & Yes (\%) & No (\%) \\
\hline 1 & $\begin{array}{l}\text { Have you visited the official destination } \\
\text { website of Maharashtra Tourism } \\
\text { (www.maharashtratourism.gov.in)? }\end{array}$ & 42 & 58 \\
2 & $\begin{array}{l}\text { Have you visited the official social media } \\
\text { pages of MTDC? }\end{array}$ & 27 & 73 \\
\hline
\end{tabular}

The tourists were asked to rate their satisfaction with the present Marketing Strategies of Maharashtra Tourism and their overall presence on the internet. The results portrayed a disappointing picture as respondents gave neutral ratings. A major reason could be that 'majority of the tourists have not seen the Marketing Contents of MTDC nor visited the official website/ social media pages of Maharashtra Tourism'.

Table 5 Satisfaction of Tourists with the Present Marketing Strategies of Maharashtra Tourism

\begin{tabular}{llc}
\hline Sr. No. & \multicolumn{1}{c}{ Statement } & Mean \\
\hline 1 & $\begin{array}{l}\text { Are you satisfied with current Marketing Strategies } \\
\text { of Maharashtra Tourism }\end{array}$ & 3.05 \\
2 & $\begin{array}{l}\text { Are you satisfied with overall presence of } \\
\text { Maharashtra Tourism on the internet }\end{array}$ & 2.94 \\
\hline
\end{tabular}

\subsection{Interview with the Marketing Manager, MTDC}

A structured interview schedule was prepared to conduct the interview with Mr Sanjay Dhekane (Marketing and Publicity Manager, MTDC, Mumbai). The interview was conducted on February 23, 2016, from 10:30 AM to 12:00 Noon.

The interview revealed the present scenario of Marketing Planning of MTDC. To achieve the marketing objective of "positioning Maharashtra as a leading tourism destination in the world", MTDC utilised diverse marketing channels such as promotional material, 
radio/TV, trade fairs and exhibitions, tourist festivals, FAM tours, internet and so forth. Among all, internet, TV and print materials were considered extremely important and they were mostly used as marketing channels by MTDC. Mr Dhekane revealed that the global reach of internet marketing differentiated itself from other traditional ways of marketing. Among various internet marketing strategies, they emphasised on Website and Social Media Marketing. He added that they were planning new social media campaigns for the year (2016).

Though MTDC found internet marketing extremely important, there was no separate department to handle the same. Mr Sanjay Dhekane and his Assistant Vrushali decided different strategies for internet marketing through discussions. Mostly the contents posted on the website or social media sites were written by out-sourced agencies and the content is approved by MTDC before publishing online. It depicted poor quality, especially for designing strategies.

Further, the interview probed into the details about the current procedures and future plans related to the official Website and Social Media Marketing. It revealed that till date the effectiveness/success of the strategies was never evaluated through the online/offline survey of tourists/users. Only post reach effect was evaluated through the number of likes, shares, comments, and website visitors. Thus, there were opportunities for future researchers to fill the gap by conducting surveys of tourists and thereby evaluate the Internet Marketing Performance of Maharashtra Tourism.

While highlighting the problems faced by MTDC in Internet Marketing Planning, Mr Dhekane raised the issue of insufficient financial and technical resources. Thus, the Data Triangulation Method was found useful in performing Situation Analysis and implementation of the present Marketing Planning Strategies of Maharashtra Tourism. The Method offered valuable inputs for SWOT Analysis, as discussed below. 


\section{SWOT Analysis of the Present Marketing Strategies of MTDC}

\subsection{Strengths of the present marketing strategies of MTDC}

\section{Reputed and well-established tourism state}

Diverse tourism products of the state, including unique products like Bollywood, Forts, Tiger Trails etc., attract tourists of all categories. The state is always one of the top two foreign tourists arriving states in the country (refer to Table 1).

2. Brand of 'Unlimited Maharashtra'

'Unlimited Maharashtra' is a well-positioned brand from the year 2002. Under the brand, 'Unlimited Maharashtra' is an awardwinning magazine of MTDC.

\section{Official destination website}

The researcher observed that the website, launched in the year 2002-03, was revamped in the year 2016 with the introduction of good graphics and features like interactive maps. The website has fine online booking facilities not only for resorts, bed and breakfast units, apartments but also for selected museums and other packages. Qualitative data collected through the interview with the Marketing Manager revealed that online booking and information quality were important features of the website. Further, it was observed that the website is supported by Google translation; hence it can be viewed in a variety of languages.

\section{Early adoption of social media marketing strategies}

Researchers observed that MTDC showed early presence on different social media channels as compared to other important tourism states of India like Rajasthan and Uttar Pradesh. 
Table 6 Social Networking Sites used by MTDC

\begin{tabular}{|c|c|c|c|}
\hline $\begin{array}{l}\text { Sr. } \\
\text { No. }\end{array}$ & Platforms & $\begin{array}{l}\text { Date of } \\
\text { Joining }\end{array}$ & Username / Account Name \\
\hline 1. & Facebook & 2012 & $\begin{array}{l}\text { Maharashtra Tourism Development } \\
\text { Corporation Ltd. (MTDC) }\end{array}$ \\
\hline 2. & Twitter & 2011 & Maharashtra Tourism \\
\hline 3. & Youtube & 2014 & MTDC \\
\hline
\end{tabular}

\subsection{Weaknesses of the present marketing strategies of MTDC:}

1. Disappointing branding strategies

Though the organisation was taking efforts for promoting the state as 'Unlimited Maharashtra', the earlier literature found that the brand did not have a very strong tagline and the low visibility affected the brand recall (Maharashtra Tourism SWOT Analysis, USP \& Competitors, 2017). There was no brand ambassador for Maharashtra Tourism. Kamble and Sawant (2017) conducted a survey of tourists at different tourism destinations of the state and they found that not everyone was aware of the brand name. Thus, though 'Unlimited Maharashtra' was an award-winning brand, there were numerous questions about brand awareness. Adding to the point, it was observed that the organisation was lagging behind in foresightedness in marketing and branding (especially brand positioning).

\section{Inadequate resources}

Qualitative data collected from the interview of the Marketing Manager of MTDC raised the issue of insufficient financial and human resources provided for internet marketing, which was a major hurdle in planning and promotion. There was no separate department or appointed employee for handling the complete digital media of MTDC. The researcher observed that other State Tourism Organisations (like Gujarat, Rajasthan) had 8-10 personnel for the same. 
3. The weakness of the official destination website

Though the State Tourism Policy (2016) aimed to develop a World Class Tourism Website to improve online presence, there was no detailed and exclusive action plan for internet marketing provided in the Tourism Policy of the state or in other documents of MTDC. Lack of promotion of the website resulted in unawareness among tourists which was reflected through the quantitative data collected through the Tourist Survey that showed that very less number of tourists visited the website (Table no. 4). Another study conducted by Satghare and Sawant (n.d.) revealed that the destination website failed to perform well in the areas of interactivity, personalisation, customisation and tour planning assistance.

\section{Weaknesses of social media marketing strategies}

Quantitative data collected through the tourist survey revealed that very less number of tourists had visited the official social media pages of Maharashtra tourism. Thus, there was the need for promotion of the pages.

Consistency was one of the most critical success factors for internet marketing, specifically for Social Media Marketing. Unfortunately, the researcher observed that MTDC posted 4-6 contents in a week on its different social media platforms and these contents were basically related to events conducted by the organisation. Thus, Maharashtra Tourism was emphasising on the use of Facebook and Twitter to create awareness about the organisation by posting organisational events, whereas the platform should have been used to create awareness about both the organisation and the destination. It was found that Kerala Tourism, an award-winning and well known DMO in the country for innovative social media marketing practices, posted on an average two contents in a day and majority of the contents were aimed at distributing information about the tourism products and services of the state.

Another crucial use of Social Media was to improve destination loyalty by engaging users through responsive contents and online competitions. Additionally, user 
engagement and two way communication were core characteristics of web 2.0, therefore, embedding such contents including 'call to action' for users, like quiz, polls, competitions etc., could enhance social activity even more. To sum up, MTDC failed to use the optimal benefits of web 2.0 which could have promoted the involvement of tourists that could have strengthened the online brand of the destination.

\section{Less involvement of stakeholders in online marketing}

Qualitative data demonstrated that MTDC did not have strategies to improve stakeholder participation in online marketing like online campaigns which could improve stakeholder engagement on the lines of Kerala Tourism which used to organise "Bid wars" every year so as to promote and sell stakeholders' packages through its Facebook page. This strengthened the stakeholder's position in customers' minds and thereby invoked the belongingness of stakeholders towards the organisation.

The official website also fell short in the area of providing a platform to the private stakeholders for marketing their products.

6. Overlooked the need for an effective Mobile app

MTDC launched a mobile app on April 06, 2016 for accommodation booking and information distribution to tourists. Pitifully the researcher observed that the application could achieve a rating of only 3.2 (retrieval on July 21, 2018) and the app was downloaded only by 10 thousand users in 2 years because of poor performance. Thus, it required an urgent refurbishment. Further, the area of specialised apps and location-based services should be focused by the Maharashtra Tourism.

7. Ignorance towards the efficient use of the internet for market research that resulted in the failure of market intelligence

Qualitative data exhibited that no surveys were conducted on the online or offline users of the website to measure the effectiveness of the website. Such a survey could have 
demonstrated the online behaviour of tourists. Further, no measurements/comparisons of Internet Marketing Strategies with other DMOs were conducted, which could have helped in ensuring quality assurance.

8. Other weaknesses

The disappointing attitude of MTDC towards innovation, experiments or creativity in the area of Digital Marketing was a major drawback of the organisation. It resulted in ineffective channel management and it failed to decide and target specific markets. The unavailability of the required digital connectivity infrastructure at the destinations and surrounding places was also counted as another weakness.

\subsection{Opportunities for MTDC}

1. Improvement of online connectivity infrastructure in the state

2. Increase in online information distribution channels

3. Political goodwill and initiatives of the government in the area of digital literacy through campaigns like Digital India

4. Improvements in online visa facility

5. New target markets

6. Untapped domestic market

7. Alliances with neighbouring states/countries/business entities for collaborative online marketing can improve promotion

8. Online Marketing of lesser known but high potential tourist destinations (like Lonar Crater)

9. Good academic research is available in the state which should be utilised to design internet marketing strategies

\subsection{Threats to MTDC}

1. Aggressive marketing by neighbouring states and countries

2. Increase in outbound tourism in India 
3. Negative promotion through online channels (especially on safety issues of women travellers)

4. Tax reforms

The above SWOT Analysis is an attempt to comprehensively analyse the current Marketing Strategies of MTDC. Hence MTDC should convert the mentioned weaknesses into strengths and take the maximum benefits of available opportunities to achieve expected growth in the tourist arrivals.

\section{References}

Chaffey, D., Chadwick, F. E., Johnston, K., \& Mayer, R. (2015). Internet marketing: strategy, implementation and practice (4th ed.). Noida: Pearson India Education Services Pvt Ltd.

Elbe, J., Hallén, L., \& Axelsson Björn. (2009). The destination-management organisation and the integrative destination-marketing process. International Journal of Tourism Research, 11, 283-296.

ETC, \& UNWTO. (2003). NTO marketing activities guidelines for evaluation. Madrid, Spain: UNWTO.

Govt of Maharshtra. (2016). Maharashtra tourism policy 2016. Mumbai: Department of Tourism and Cultural Affairs, Government of Maharashtra.

Joshi, V. M. (2014). Development and marketing of tourism in Maharashtra. IJMBSPrint) International Journal of Management $\mathcal{E}$ Business Studies, 4(21), 2230-9519. Retrieved from http:// www.ijmbs.com/Vol4.4/spl1/4-Dr-Vandana-M-Joshi.pdf

Kamble, P., \& Sawant, M. (2017). No Title. Unpublished raw data.

Maharashtra Tourism SWOT Analysis, USP \& Competitors. (2017). Retrieved July 4, 2017, from http://www.mbaskool.com/ brandguide/tourism?and?hospitality/3331?maharashtra?tourism.htm 1

MoT GoI. (2016). India Tourism Statistics at a glance 2015. Ministry of Tourism. New Delhi: Ministry of Tourism, GoI. http:// doi.org/ 10.1787/eag-2013-en

MTDC. (2005). The information of Maharashtra tourism development corporation limited. Mumbai: MTDC. Retrieved from https:// www.maharashtratourism.gov.in/mtdc/about

MTDC. (2015). Tourism Survey for the State of Maharashtra April 2014 to March 2015. Mumbai.

Pike, S. (2004). Destination Marketing Organisations. London: Elsevier Ltd.

Satghare, H., \& Sawant, M. (n.d.). Evaluation of official destination 
website of Maharashtra state (India) from the customer perspective. Submitted for publication in Journal of Global Scholars of Marketing Science: Bridging Asia and the World.

Tanrisevdi, A., \& Duran, N. (2011). Comparative evaluation of the official destination websites from the perspective of customers. Journal of Hospitality Marketing \& Management, 20(7), 37-41. http:// doi.org/ 10.1080/19368623.2011.577708

Thadani, M., \& Roy, S. (2017). India State Ranking Survey. Gurugram. Retrieved from http://www.travelbizmonitor.com/ ArticleImages/ 2017/11/30/State Ranking Survey 2017 .pdf

Tourism. (2014). Retrieved from http:// planningcommission.gov.in/ plans/stateplan/sdr_maha/ch-12-14-02-05.pdf

Yayli, A., \& Bayram, M. (2010). Web-based destination marketing: Do official city culture and tourism websites' in Turkey consider international guidelines? Tourism: Preliminary Communication, 58(1), 51-60.

Yeasmin, S., \& Rahman.K.F. (2012). 'Triangulation' research method as the tool of social science research. Bup Journal, 1(1), 154-163. Retrieved from

http://bup.edu.bd/assets/uploads/journal_content_file/1511259502 154-163.pdf. 